\title{
O contínuo da argumentação: polêmica e persuasão no discurso político
}

\section{The continuous of argumentation: polemic and persuasion in political discourse}

\author{
Patrícia da Silva Valério ${ }^{1}$ \\ Fernanda Lopes Bortolini² \\ Christina Gnoatto Zart ${ }^{3}$
}

DOI: $10.28998 / 2317-9945.2020$ n64p120-132

\section{Resumo}

Este artigo objetiva analisar como se constrói a argumentação no discurso de dois pré-candidatos à presidência na eleição de 2018 no Brasil, verificando quais estratégias discursivas são mobilizadas e que efeitos de sentido elas constroem na interação. O corpus consta de dois recortes de entrevistas televisivas, concedidas ao Programa Roda Viva, da TV Cultura, no periodo entre abril e julho de 2018. Para responder ao objetivo, é mobilizado o conceito de linguagem, a partir da perspectiva social da linguagem, de Bakbtin e seu Círculo (2010a, 2010b), e, ainda, o conceito de argumentação e polêmica, com base em Amossy (2017). Os procedimentos utilizados configuram este estudo como bibliográfico, com uma abordagem qualitativa e de caráter exploratório. O corpus analisado revela a presença da argumentação na fala de ambos os pré-candidatos, uma vez que a argumentação não é uma prova de verdade, e sim uma estratégia linguistica para persuadir o interlocutor. A análise elucida, ainda, a existência de um contínuo revelador de uma polarização constitutiva da argumentação, que se concretiza na interação discursiva.

Palavras-chave: Interação discursiva. Argumentação. Polêmica. Discurso

\begin{abstract}
This paper aims to identify how the argument is constructed in the discourse of two pre-candidates in the 2018 election in Brazil, verifying which discursive strategies are mobilized and what effects of meaning they construct in the interaction. The corpus consists of two interview excerpts from Roda Viva, a TV Cultura's TV show, which were broadcasted in the period between April and July of 2018. To that end, it is articulated the concept of language, from the social perspective of language, based on Bakhtin and his Circle (2010a, 2010b), as well as the concept of argumentation and polemics, based on Amossy (2017). Considering its methods, this study can be understood as bibliographic, with a qualitative and exploratory approach. The corpus analyzed reveals that argumentation is present in both pre-candidate's speech, once argumentation is not a proof of truth, but a linguistic strategy to persuade the interlocutor. The analysis also explains the existence of a continuous that reveals a polarization which is part of the argumentation and materializes itself in the discourse.
\end{abstract}

Keywords: Discursive interaction. Argumentation. Polemic. Discourse

Recebido em: 27/05/2019.

Aceito em: 02/08/2019.

\footnotetext{
${ }^{1}$ Doutora em Linguística Aplicada pela Universidade do Vale do Rio dos Sinos (Unisinos). Docente do Curso de Letras e do Programa de Pós-graduação em Letras da Universidade de Passo Fundo.

${ }^{2}$ Mestranda do Programa de Pós-graduação em Letras da Universidade de Passo Fundo.

3 Acadêmica do curso de Letras (Português e Inglês) da Universidade de Passo Fundo.
} 


\section{Considerações iniciais}

O ano de 2018 foi marcado por pleito eleitoral com manifestações intensas, polarização e por certa emergência do dizer - dizer para defender propostas, pontos de vistas, persuadir. Assim, circularam, em diversas esferas discursivas, muitos textos orais e escritos, de distintos gêneros do discurso político - entrevistas escritas, entrevistas televisivas, debates, roda de conversa, além de muitas postagens em redes sociais.

Diante da circulação de número expressivo de textos e discursos em torno do tema eleições para a presidência da república, decidimos analisar dois recortes de entrevistas televisivas concedidas ao Programa Roda Viva, da TV Cultura, de dois pré-candidatos: um primeiro recorte da entrevista do, então, pré-candidato à presidência da República, Jair Messias Bolsonaro, atualmente presidente eleito, concedida ao Programa no dia 30 de julho de 2018, e um segundo recorte de entrevista da pré-candidata à presidência da República, Marina Silva, realizada em 30 de abril de 2018. Buscamos analisar como se constrói a argumentação no discurso de dois pré-candidatos à presidência na eleição de 2018 no Brasil, verificando que estratégias discursivas são mobilizadas e que efeitos de sentido elas constroem na interação.

Para buscar responder a este objetivo, assumimos a concepção de linguagem de Bakhtin e seu Círculo, mobilizando conceitos sobre a natureza polêmica da argumentação, de Ruth Amossy (2017). Os procedimentos utilizados para realização deste estudo configuram-no como bibliográfico, com uma abordagem qualitativa e de caráter exploratório (PRODANOV; FREITAS, 2013).

Este artigo está estruturado da seguinte forma: na primeira seção, definimos o conceito de linguagem social e dialógica, a partir da perspectiva de Bakhtin e o Círculo ${ }^{4}$ (2010a, 2010b), passando, na segunda seção, pela origem do conceito de argumentação ao conceito atual, com base em Amossy (2017). Na terceira seção, apresentamos a metodologia e a análise dos recortes selecionados.

\section{Concepção social de linguagem - dialógica}

Assumimos a perspectiva dialógica da linguagem defendida por Bakhtin e seu Círculo, segundo a qual a linguagem é sempre o produto da interação verbal, isto é, o produto da interação entre o locutor, o ouvinte e o auditório social.

Compreender a interação nessa perspectiva significa entender que viver é participar de um grande diálogo, que compreende a interação face a face, mas principalmente o diálogo em sentido amplo. Isso significa que todo discurso - escrito ou falado - constitui apenas uma parte de uma comunicação verbal ininterrupta. Assim, qualquer enunciado responde sempre a alguma coisa: confirma, refuta, antecipa respostas, procura apoio. Nas palavras de Bakhtin (2010a, p. 129): "a enunciação realizada é como uma ilha emergindo de um oceano sem limites, o discurso interior. As dimensões e as formas dessa ilha são determinadas pela

\footnotetext{
4 Adotamos esta denominação tardiamente atribuída pelos estudiosos das obras produzidas por um grupo multidisciplinar, composto por jovens intelectuais das mais diferentes áreas, entre os quais destacam-se Mikhail M. Bakhtin, Pavel N. Medvedev e Valentin N. Volochinov (FARACO, 2003).
} 
situação da enunciação e por seu auditório", os quais determinam as escolhas das palavras que moldam os enunciados.

Nesse sentido, a interação constituirá sempre um evento único e irrepetível, no interior do qual se manifestam relações dialógicas, isto é, relações de sentido (BAKHTIN, 2010b). As relações dialógicas são complexas, pois os enunciados terão sempre uma face verbal (o dito) e uma face não verbal (o presumido), que será depreendida a partir da situação (contexto) e da compreensão do interlocutor (leitor ou ouvinte). Por isso, os enunciados emergem em uma espécie de guerra de discursos, na qual forças centrípetas (centralizadoras, monológicas) atuam para tentar apagar ou dispersar forças centrífugas (que combatem as forças centralizadoras) (FARACO, 2003).

A partir dessa perspectiva, que adota a interação como princípio de linguagem, é importante lembrar que o sentido jamais será pré-estabelecido, algo a ser identificado ou decifrado, mas dependerá sempre da relação entre os sujeitos, portanto somente poderá ser construído na produção e na interpretação dos textos.

Definida a perspectiva de linguagem adotada neste texto, passamos à apresentação do conceito de argumentação, a partir de Amossy (2017), uma vez que esse conceito será importante para compreender o modo como interpretamos os dados desta pesquisa.

\section{Breve panorama dos estudos da argumentação: retórica, nova retórica e polêmica}

Para compreender a argumentação, vamos nos voltar brevemente ao estudo da retórica aristotélica, base da filosofia e da sociedade na qual surgiu a democracia, a partir do que Ruth Amossy postula na obra Apologia da Polêmica (2017). Aristóteles, o filósofo grego, defendia que a retórica era a arte de argumentar, não apenas persuadir, mas sim tecer os argumentos, baseados em verdades, de acordo com o contexto em que se situam, recorrendo à Lógica. Segundo Amossy (2017), a retórica é a arte da negociação das diferenças, que visa chegar a um acordo, sendo que a diversidade de opiniões, até mesmo opostas, é trabalhada verbalmente para chegar à decisão e à ação coletiva. Nessa busca de acordo, faz-se presente o dissenso, que é considerado o motor inconteste da democracia (AMOSSY, 2017).

$\mathrm{Na}$ retórica, o uso regrado da fala segue vias racionais para resolver conflitos de opinião: "em suma, uma regulação do discurso público entendido como um exercício do logos, do discurso razoável, se impõe para concretizar a busca de um acordo, objetivo maior de qualquer deliberação bem compreendida" (AMOSSY, 2017, p. 20).

Porém, o que se desvia dessa definição pode ser enquadrado no que se chamou na antiguidade de erística, "arte indigna e sem a sabedoria da disputa" (ANGENOT, 2008 apud AMOSSY, 2017, p. 21). A retórica toma o cuidado de não cair na erística, o jogo verbal que não tem compromisso com a verdade ou com a razão, no qual não se conserva o respeito pela ética (AMOSSY, 2017). A erística tem seu nome herdado da deusa da mitologia grega, Eris - que significa discórdia, disputa, desunião - irmã de Ares, deus da guerra, o que relaciona a erística ao conflito desregrado.

De acordo com Amossy (2017), dois pensadores contemporâneos que se voltam para o estudo da retórica, em 1970, Perelman e Olbrechts-Tyteca, fazem uma distinção de debate e discussão. Para eles, a discussão busca a verdade plena (por meio da razão/logos), e o 
debate, comparado com a erística, apenas busca triunfar uma opinião sobre a outra - podendo recorrer à violência e à manipulação no discurso. Então, Perelman defende uma nova retórica, na qual há uma valorização do acordo. É papel da nova retórica, elevar as interações que consigam resultar em um consenso dos espíritos, preocupando-se com a ética. Segundo Amossy (2017), o interesse da nova retórica é no raciocínio verbal desenvolvido quando o objetivo é o acordo e o instrumento da busca é a razão. A valorização do acordo, em Perelman, revela-o como símbolo de racionalidade, "na verdade, é o acordo dos espíritos sobre o que parece aceitável que funda na razão um posicionamento ou uma opinião. Nessa perspectiva, a busca pelo consenso compreende questões ao mesmo tempo filosóficas e sociais" (AMOSSY, 2017, p. 22). Ou seja, é preciso superar o dissenso, o que significa seguir a racionalidade para evitar a divisão que gera conflitos.

As teorias da argumentação que vieram depois da nova retórica mantiveram o acordo em posição privilegiada. Esta era também a posição de Habermas, para quem o espaço público é do diálogo "gerido pelo discurso argumentado, pela cooperação consentida no diálogo arrazoado em prol de uma solução negociada para problemas comuns" (HABERMAS, 1993 [1962] apud AMOSSY, 2017, p. 27). A busca pela harmonia social segue prevendo que o dissenso seja superado pelo consenso: "o espaço público exige que um debate racional leve a tomadas de decisão coletivas por meio de um acordo. A retórica persuasiva, da qual dá conta às teorias da argumentação e da comunicação contemporânea, encontra nessas premissas sua razão de ser" (AMOSSY, 2017, p. 29). Por outro lado, é importante refletir sobre a questão da persuasão e se a abordagem baseada na razão leva necessariamente ao acordo. Sobre isso, Fogelin, outro autor citado por Amossy (2017), conceitua os desacordos profundos, que ocorrem quando a base argumentativa dos sujeitos tem princípios diferentes, reforçados mutuamente por paradigmas. Fogelin usa a tese de Wittgenstein para reforçar seu conceito e faz uma crítica à abordagem dedutiva pura:

A comunicação argumentativa normal implica um conjunto de crenças compartilhadas e um acordo de base sobre os procedimentos de resolução de desacordos. $\mathrm{Na}$ ausência dessas condições, a argumentação se revela impossível: Minha tese, ou melhor, a de Wittgenstein, é que os desacordos profundos não podem ser resolvidos pelo uso de argumentos, porque eles minam as próprias condições que autorizam a argumentação (AMOSSY, 2017, p. 30).

Entende-se disso que há debates que permanecem impermeáveis ao processo de consenso atingido através do debate arrazoado, e por isso o assunto segue gerando estudos, como o de Angenot sobre os diálogos de surdos. Segundo Amossy (2017), Angenot faz um contraponto a Fogelin, defendendo que as discussões que não chegam a um acordo são a regra, e não a exceção. Muitas vezes, a interação verbal é uma tentativa de influência persuasão de sua vaidade - e Angenot acredita que as pessoas fazem questão de argumentar para justificarem-se, não necessariamente para outras pessoas, mas talvez por uma questão de manter a consciência limpa. Amossy (2017) mobiliza ainda as postulações de Coser, que trabalha conceitos que circundam o conflitual, dividindo o conflito em duas categorias: realistas - apenas um objetivo, podem variar os meios para alcançá-lo - e os não realistas podem usar meios agressivos, demostram que podem mudar de alvo, mas não de meio. A divisão permite entender melhor os conflitos sociais, como luta por recursos limitados exemplo: reinvindicação salarial - ou luta pelo poder. Na perspectiva de Coser, segundo Amossy (2017), o dissenso é revalorizado, abrindo espaço para funções positivas do conflito polêmico, que é necessário para expressar revolta em situações de opressão. Mouffe vai de encontro a esse ponto de vista, pois, para ele, a democracia depende do dissenso, no sentido que existe um "nós" na mesma medida que existe um "eles" e esse antagonismo se sustenta 
no modelo democrático. O "eles" do "nós" na política deve ser encarado como um adversário, mas não como um inimigo. Portanto, é necessário "lutar", por meio da fala, defendendo um posicionamento, mas não eliminar/destruir o adversário, através de uma fala que faça uso da violência.

Porém, no contexto político ou mesmo fora dele, em se tratando do homem, é comum buscar sobressair a própria opinião sobre a do outro, mesmo que isso signifique ignorar a racionalidade; o que foi explorado na obra $A$ arte de ter sempre razão (1864), do filósofo alemão Schopenhauer, que defende a "dialética erística". Segundo Amossy (2017), ao analisar a natureza humana - a vaidade dos homens e sua desonestidade -, o filósofo percebeu que esses preferem triunfar a própria tese, desviando-se da busca da verdade. Dessa forma, Schopenhauer faz um contraponto a Perelman, pois defende que não é possível basear as questões humanas na racionalidade e as disputas na idealização do acordo, uma vez "que se baseia na inevitabilidade de dissensão e da luta verbal, aparece nos estudos atuais da polêmica como um pai fundador" (AMOSSY, 2017, p. 39).

Sobre o dissenso, Dascal, outro autor citado por Amossy (2017), faz uma importante contribuição, distinguindo conceitos de: discussão, disputa e controvérsia. $O$ primeiro conceito visa estabelecer a verdade; o segundo visa à vitória, enquanto o terceiro tem por objetivo a persuasão. $\mathrm{O}$ autor se volta ao contexto científico e defende que são as teses antagônicas, movidas pela polêmica e pelo dissenso, que proporcionam as pesquisas, o que se dá por meio da persuasão. Por mais que nem sempre uma tese se prove verdadeira, a defesa dela propicia que outra tese exista para esclarecer e refutar seus aspectos, fazendo com que as discussões se mantenham ativas na academia. Nessa perspectiva, não há acordo nos casos de controvérsias científicas (acadêmicas), filosóficas e polêmicas públicas.

Outro conceito importante sobre a característica conflitual presente na polêmica é de dicotomização, conceito abordado por Amossy (2017), a partir de Dascal. A dicotomização coloca em pauta opiniões contraditórias que se excluem mutuamente; ela "radicaliza o debate, tornando-o difícil - às vezes impossível - de resolver" (DASCAL, 2008 apud AMOSSY, 2017, p. 53). Como contraponto, surge o conceito de desdicotomização, o qual mostra que a oposição pode ser construída de modo menos coercitivo que uma contradição; vislumbra, portanto, a possibilidade de construir uma abertura passível de negociações e busca de solução.

Alinhada a essa perspectiva, surge, em outro enquadre contextual, a compreensão da polêmica como sendo o espaço discursivo com dois polos, isto é, pares de oposição, dos quais cada uma das partes se apropria do discurso do outro, opondo-o ao seu próprio discurso (MAINGUENEAU, 1983 apud AMOSSY, 2017). Tal conceito interessa-nos sobremaneira, uma vez que define a polêmica nas questões de interesse público, tal como na esfera política por "uma gestão do conflitual, caracterizada por uma tendência à dicotomização, que torna problemática a busca por um acordo" (AMOSSY, 2017, p. 55). A polêmica é de ordem social, portanto os autores recomendam examinar com atenção a relação com o outro e alertam para o surgimento da polarização, conceito que coloca em jogo a existência de grupos antagônicos, que constituiriam um "nós" diante de um "eles". A polarização supõe a existência de um inimigo comum e seu discurso objetiva desqualificar o autor de uma determinada ideia, visa atingir um alvo, gerando o descrédito do adversário e do discurso que ele sustenta (KERBRAT-ORECCHIONI, 1980 apud AMOSSY, 2017).

Esses papeis que "nós" e "eles" assumem na polarização podem levar à necessidade de rebaixar o discurso do "outro", pois ao "atacar" a pessoa atinge automaticamente seu 
discurso; isso é chamado de desqualificação do oponente. Nesse sentido, o oponente é considerado uma espécie de inimigo, alguém que deve ser silenciado ou excluído do diálogo. Então o "descrédito lançado sobre as pessoas anula a força de seus argumentos" (AMOSSY, 2017, p. 59).

Contudo, a autora afirma que seria equivocado crer que toda polêmica contém violência verbal, pois esta não é uma característica definidora sua, ainda que, muitas vezes, seja parte integrante da argumentação polêmica. Podemos colocar o exemplo das discussões em redes sociais, que não seguem regras; ou debates políticos televisivos, que, por outro lado, seguem um molde que é regrado.

\begin{abstract}
Essa tensão entre o jogo regrado, a competição codificada e a violência dos ataques verbais é fundamental para o bom funcionamento da polêmica pública. Ela tem, efetivamente necessidade de lugares institucionais em que ela possa se desenvolver, e que lhe conferem, pelo menos em parte, seu sentido em função de suas finalidades (ajudar na escolha de um presidente, permitir uma discussão cidadã não midiatizada etc.). Por que a polêmica, não se deve confundir, não é uma fala selvagem. Ela toma corpo num espaço democrático que a autoriza e a regula ao mesmo tempo (AMOSSY, 2017, p. 65).
\end{abstract}

Vale lembrar que a polêmica pública, além do "nós" e "eles", prevê uma "plateia" que assiste, permite que as mídias lucrem com o "espetáculo" gerado pela polêmica. Segundo Amossy (2017, p. 66), a influência das mídias acaba invertendo a lógica da troca polêmica, tratando de persuadir o Terceiro, derrotando o Oponente ao invés de dialogar com ele para convencê-lo. A autora destaca a relevância de se recolocar o discurso polêmico no campo da argumentação.

A explanação, ainda que rápida, sobre os diversos conceitos que se inter-relacionam quando se discute argumentação mostra a complexidade do tema, que não pode ser reduzido a um ou outro sentido apenas. Para tanto, Amossy (2017, p. 67) propõe que a argumentação seja pensada como um contínuo em torno de uma mesma questão:

No centro, encontra-se a argumentação como troca regrada de teses antagônicas: em um dos polos, o discurso visando à persuasão que não ataca diretamente a posição contrária, e não apresenta a posição do outro e finge não ter nenhuma visada de influência; e, no outro polo, o choque de teses antagônicas que dizem respeito à polêmica.

Após realizarmos este percurso, com vistas a definir o conceito de linguagem que assumimos (BAKHTIN, 2010a, 2010b), passando pela origem do conceito de argumentação ao conceito atual, com base em Amossy (2017), apresentamos a metodologia e análise dos recortes selecionados.

\title{
Percurso metodológico e análise
}

Mobilizamos dois excertos de entrevista televisiva de dois, então, pré-candidatos à presidência na eleição de 2018 no Brasil, a fim de analisar como se constrói a argumentação no discurso de ambos, verificando que estratégias discursivas são mobilizadas e que efeitos de sentido elas constroem nessa interação. 
O primeiro excerto de entrevista é o do, então, pré-candidato, Jair Messias Bolsonaro, que retextualizamos - texto oral ao texto escrito - para proceder à interpretação. A entrevista televisiva teve duração de $1 \mathrm{~h} 21 \mathrm{~min} 50 \mathrm{~s}$, e como formato já consagrado do Programa Roda Viva, o entrevistado fica no centro da roda envolto pela bancada de entrevistadores convidados. Ao longo da entrevista, inúmeros temas foram abordados, tais como: economia; estratégia política; reforma da previdência; planos de governo; posicionamento ante temas como aborto, homofobia, misoginia, arquivos da ditadura, tortura, estupro, caixa dois, cotas, etc. Nossa escolha temática se dá por uma das interações polêmicas. Abaixo segue trecho recortado da entrevista ( $31 \mathrm{~min}$ a $32 \mathrm{~min} 40 \mathrm{~s}$ ), que configura uma pergunta e uma resposta:

Convidado 1: Hoje mesmo o jornal suiço Tribune de Genève chamou o candidato de homofóbico, misógino e racista e chamou o senhor de Trump brasileiro. Sabemos que o Trump épara o senhor alguém que você admira e eu gostaria de saber, na sua opinião, o que o senhor tem em comum com o presidente americano e o que o senhor difere dele?

Pré-candidato: Primeiro, se eu sou racista eu tinha que estar preso. Eu não tenho imunidade, se eu ofender um afrodescendente agora, impedir de entrar no elevador tá, isso é crime de racismo eu tenho que ser preso mesmo sendo deputado federal, são calúnias.

Convidado 2: O senhor já foi denunciado criminalmente candidato.

Pré-candidato: São calúnias, nada mais e além disso, calúnias. Como a questão de homofóbico, a minha briga é contra o material escolar. Você sabe se eu sou homossexual ou não? Você não sabe, e eu não sei se você é ou não, e não interessa para nós. O que não pode é o pai chegar em casa e encontrar o Joãozinho de seis anos de idade brincando de boneca por influência da escola. Misógino? Por que que eu sou misógino? Por que que eu não gosto de mulher?

Convidado 1: Essa é a imagem que o jornal suiço tem do senhor.

Pré-candidato: Mas a imprensa é quase toda de esquerda no mundo, não viu o que o Trump passou? O Trump sofreu muito com isso, fake news (RODA VIVA, 2018).

A primeira leitura que depreendemos é de que o entrevistado assume, como força de argumento, a negação. Nega o que o convidado 1 afirma em sua pergunta: "o jornal suiço Tribune de Genève chamou o candidato de homofóbico, misógino e racista e chamou o senhor de Trump brasileiro". E passa a defender a tese de que ele é vítima de calúnia, ou seja, afirma que são mentiras o que a imprensa internacional e nacional tem publicado sobre ele. Vai reforçando a tese ao longo da resposta "calínia, calúnia e calúnia", repetindo argumento, a fim de que seus interlocutores primeiros - convidados do programa televisivo - e todos os demais interlocutores - os telespectadores e possíveis eleitores - que compreende todo o auditório social, de que essas afirmativas não passam de mentiras. Isto é, convoca uma interlocução dos que apoiam discurso subjacente em parte do auditório social de que o pré-candidato é uma vítima constante de fake news, propagadas pela imprensa nacional e internacional.

Para a sustentação do argumento de negação, apresenta um argumento complementar e falacioso: "se en sou racista en tinha que estar preso". Embora saibamos que, no Brasil, o racismo é crime, conforme prevê a Lei 7.716, chamada de Lei Caó, e também a injúria racial, prevista no artigo 140 do Código Penal Brasileiro, é evidente que, no país, são mínimos os casos em que crimes de racismo e injúria racial são julgados. Vivemos um racismo velado, já que raramente um sujeito racista é preso, o que ocorre, no máximo, é o 
desencadeamento de processo penal, sendo que, muitas vezes, o acusado resulta impune. Nesse sentido, a afirmação do candidato de que "se eu sou racista eu tinha que estar preso", ainda que não tenha relação com a verdade (ou a realidade), configura-se como um argumento. Conforme Platão e Fiorin (2003), um argumento não é necessariamente uma prova de verdade, mas um recurso, de natureza linguística, usado pelo locutor para convencer o interlocutor.

No segmento em análise, o pré-candidato segue construindo sua argumentação que recorre à negação, fazendo uso da digressão ${ }^{5}$ em três situações: não ser racista; não ser homofóbico; não ser misógino. Sobre não ser racista, ele ainda faz uso do eufemismo com o emprego do termo "afrodescendente", evitando, inclusive, o termo negro, para não parecer ${ }^{6}$ ser racista.

Quando o pré-candidato declara não ser homofóbico, sabemos que a afirmação pode ser refutada, pois há várias declarações anteriores à entrevista em que o candidato faz uso de falas preconceituosas, como podemos ler, por exemplo, em uma matéria como a do El País (2018), intitulada “O que Bolsonaro já disse de fato sobre mulheres, negros e gays", que reúne todas as frases controversas ditas pelo pré-candidato, e cita uma, em que ele afirma ser incapaz de amar um filho gay e que "Prefiro que um filho meu morra num acidente do que apareça com um bigodudo por aî". Além disso, o que ele diz ser contra é que "o que não pode é o pai chegar em casa e encontrar o Joãozinho de seis anos de idade brincando de boneca por influência da escola", fazendo referência ao livro Aparelho Sexual e Cia, do autor suíço Philippe Chappuis, que esteve no centro de polêmicas, por supostamente integrar um possível "kit gay" que, segundo o candidato, teria sido entregue, pelo Ministério da Educação, às escolas do país pelo governo "do PT". Essa informação, sabidamente, é falsa, uma vez que nenhum "kit gay" foi entregue às escolas pelo governo ${ }^{7}$. Segundo o Ministério da Cultura (Minc), vinte e oito exemplares do livro "Aparelho sexual e Cia: um guia inusitado para crianças descoladas" foram comprados em 2011 através de um Programa chamado Livro Aberto, que tinha como foco bibliotecas em geral, e não exclusivamente bibliotecas escolares ${ }^{8}$.

A terceira digressão põe em foco a negação de misoginia. Sobre esse tema, ele apenas indaga “Misógino? Por que que eu sou misógino? Por que que eu não gosto de mulher?”. Seria possível contestar a fala do pré-candidato, a partir do que dissera na Tribuna da Câmara, quando ainda era deputado, que não estupraria a colega Maria do Rosário, porque ela "não merece". Por esse pronunciamento, Bolsonaro, em 2017, foi condenado pela terceira vez a indenizar a deputada federal por danos morais, como pode ser lido na matéria "Pela terceira vez, Bolsonaro é condenado a indenizar Maria do Rosário", da Carta Capital (2017). Isto é, o précandidato faz uso de um discurso tautológico, para se esquivar da afirmativa de ser misógino.

\footnotetext{
${ }^{5}$ A digressão se dá pela desfocalização do tema, isto é, o entrevistado não responde diretamente à pergunta, mas tópicos presentes na contextualização da pergunta.

${ }^{6}$ Seria importante aprofundar a reflexão sobre o uso de eufemismos na tentativa de mascarar o preconceito. Em razão dos limites deste artigo, não exploraremos aqui esta discussão, que nos parece bastante pertinente. ${ }^{7}$ Essa falsa notícia, que circulou amplamente nas redes sociais, foi tema de grande polêmica durante o período pré-eleitoral. Diversas fontes confiáveis abordaram o tema na época, como, por exemplo, os jornais Zero Hora (https://gauchazh.clicrbs.com.br/comportamento/noticia/2018/08/bolsonaro-usa-informacoes-falsas-aocriticar-livro-sobre-educacao-sexual-cjlfhyhp905bd01qkq80twhf5.html. Acesso em: 1 ago. 2019) e Folha de São Paulo (https://veja.abril.com.br/politica/tse-manda-tirar-do-ar-fake-news-de-bolsonaro-sobre-kit-gay/ Acesso em: 1 ago. 2019).

8 Informação disponível em: http://g1.globo.com/educacao/noticia/2016/01/livro-de-educacao-sexual-alvo-deboato-foi-comprado-pelo-minc.html. Acesso em: 1 ago. 2019.
} 
Nossa leitura mostra que, embora o pré-candidato não tenha respondido objetivamente à questão posta: "Sabemos que o Trumpé para o senhor alguém que você admira e en gostaria de saber, na sua opinião, o que o senhor tem em comum com o presidente americano e o que o senhor difere dele?", não podemos afirmar que não tenha usado argumentos. Como ensinam Platão e Fiorin (2003), o candidato fez uso de um recurso argumentativo de natureza linguística, já que um argumento não é, necessariamente, uma prova de verdade, como já mencionamos.

O que se observa na construção da argumentação do pré-candidato é o uso de uma estratégia argumentativa que revela não só a compreensão de sua situação discursiva, como a mobilização da linguagem exata a ser compreendida pelos seus interlocutores, ou seja, seu auditório social, visto que a emissora cria um palco, que visa um auditório que vai além dos convidados, mas se dirige ao seu horizonte social, à plateia que assiste, a qual aceita seu discurso e concorda com ele, apesar da facilidade de refutação dos argumentos. Importante observar que não era aos convidados entrevistadores a quem ele se dirigia, e sim aos telespectadores, a quem ele disse e repetiu que estava sofrendo calúnia. A boa mobilização da competência linguística bastou, neste contexto, para conversar com o seu auditório.

Tais estratégias mobilizadas pelo pré-candidato, acima apontadas, revelam que essa construção argumentativa está ligada à maneira como o convidado 1 constrói seu discurso na interação. Sobre essa construção, há um elemento bastante significativo para nossa análise, no que se refere ao contínuo de argumentação definido por Amossy (2017). A autora afirma que argumentação deve ser pensada como um contínuo em torno de uma mesma questão, em que no centro está a argumentação como troca regrada de teses antagônicas, e em um dos polos encontra-se o discurso visando à persuasão - que não almeja atacar diretamente a posição contrária, e finge não ter visada de influência -, e no outro polo, está a polêmica, que se constitui do choque entre teses antagônicas.

Nossa leitura foi de que o convidado 1 trouxe um discurso de autoridade, o jornal Tribune de Genène, que usa qualificadores que potencializaram a polêmica nessa interação, tais como homofóbico, misógino e racista. A partir dessa construção, o pré-candidato assume como ataques a sua pessoa, feitos pelo convidado 1, então, ele passa a se defender, sem responder à pergunta. E passa a negá-las, como forma também de se defender dessas acusações. Tal estratégia se solidifica quando o convidado 2 interrompe a resposta do précandidato para dizer: "O senhor já foi denunciado criminalmente, candidato", aproximando seu argumento da erística - desacordo profundo -, pois tal afirmação tem intenção de atacar o pré-candidato, silenciando-o.

Nesse sentido, essa interação pode ser alocada no contínuo da argumentação, no polo da polêmica, pois a forma como foi construída a pergunta reflete na forma como foi construída a resposta, visto que um enunciado só se constrói, visando seu interlocutor e seu auditório, os quais determinam as escolhas das palavras que moldam os discursos. Os convidados revelam a intenção de transformar o programa em palco de embates para um grande auditório, recorrendo ao que é polêmico e que divide as opiniões de forma a prender a atenção dos interlocutores. Conforme argumenta Amossy (2017), a polêmica pública intensifica a oposição entre um "nós" e um "eles", na medida em que prevê uma "plateia" que assiste e que permite que as mídias lucrem com o "espetáculo" gerado. A lógica da troca polêmica, dessa forma, visa persuadir o terceiro envolvido - auditório social - a partir da derrota do oponente, e não do convencimento pelo diálogo.

Em suma, percebemos que tal interação resultou em uma argumentação polêmica já na construção da pergunta inicial, o que provavelmente levou o interlocutor a assumir uma 
defesa, a partir da negação das afirmativas, como se defendesse sua honra, sua pessoa. Dessa forma, estabeleceu na digressão a oportunidade de criar uma estratégia discursiva, embasada na competência linguística, a fim de levar o auditório daquela interação a aceitar sua tese, por mais frágil ou falaciosa que pareça. Somente como forma de sublinhar nossa análise, ao longo de toda a entrevista, a polêmica foi mobilizada como estratégia argumentativa, e a cada volta de intervalo do programa, o âncora anunciava que a entrevista estava entre os assuntos mais comentados da rede social Twitter daquele dia, ou seja, a polêmica, nesse caso, de fato foi importante recurso na garantia da plateia, isto é, da audiência.

O segundo recorte de entrevista é da pré-candidata Marina Silva. Na totalidade, a entrevista teve duração de $1 \mathrm{~h} 20 \mathrm{~min} 44 \mathrm{~s}$, sendo que recortamos, para análise, trecho de cerca de quatro minutos, entre $26 \mathrm{~min} 12 \mathrm{~s}$ a $30 \mathrm{~min} 20 \mathrm{~s}$, configurando uma pergunta e uma resposta, em que a temática é Direito da população LGBT+:

Convidado: Nós vivemos em um país bastante violento e preconceituoso quando se toca no tema da população LGBT. Calcula-se que só no ano passado cerca de 179 pessoas trans e travestis foram assassinadas pelo fato de serem pessoas trans e travestis. É uma taxa de assassinato de pessoas trans a cada $48 \mathrm{~h}$ no país. Brasil lidera, portanto, os indices mundiais de transfobia. Há um sentimento por outro lado difundido na população LGBT que enxerga uma certa desconfiança e credita uma falta de clareza do posicionamento da candidata. Como a senhora avalia essas críticas e como se posiciona hoje em relação ao tema como casamento gay, sobre a adoção por casais do mesmo sexo, criminalização da bomofobia [..], em resumo, o que a população LGBT desse país pode esperar de um possivel governo de Marina Silva, caso a senhora seja eleita?

Pré-candidata: Olha, en acho que é esse debate é muito relevante porque não se pode aceitar nenhuma forma de discriminação, de preconceito contra qualquer pessoa. Acho que o preconceito é umas das piores formas de lidar com a condição bumana porque ela parte de ideias, que como diz a própria palavra são pré-concebidas. Todas as pessoas têm que ser respeitadas, independente da cor, da condição social, orientação sexual ou do credo religioso. Nós vivemos em um estado laico, e no estado laico as pessoas têm que ser respeitadas independente dessas situações a que me referi antes. Você falou que algumas pessoas têm algum tipo de... preocupação em relação a minha pessoa e talvez. isso seja em função de um preconceito também pelo fato de eu ser uma pessoa de fé. Nos meus anos todos de vida pública sempre defendi os Direitos Humanos. E em relação a questão do casamento gay, o Conselho Nacional de Justiça já estabeleceu que é um direito o casamento civil para a população LGBT. Isso é um direito que já está estabelecido e qualquer forma de violência [...] é inaceitável e sobre a adoção de crianças por casais homoafetivos, no meu programa em 2010 e 2014,[...] isso já foi estabelecido que a gente botar o foco na criança, uma vezpassando pelos controles que é feito a qualquer casal, está classificado e tem o direito de adotar. Então é uma agenda que precisa ser tratada, eu sempre digo que não se pode negligenciar o preconceito contra indios, negros, gays, mulheres, ciganos, e as pessoas que vivem em situação de vulnerabilidade (RODA VIVA, 2018).

Neste excerto, percebemos que a pré-candidata assume um argumento inegavelmente favorável aos Direitos humanos ou, nas palavras dela, "nos meus anos todos de vida pública sempre defendi os Direitos Humanos", assumindo como tese ser contra o racismo, a homofobia, a discriminação de minorias.

Para construir sua argumentação, a pré-candidata evoca argumentos de autoridades, como a CNJ sobre a legalização do casamento civil entre pessoas do mesmo sexo, isto é, " $E$ em relação a questão do casamento gay, o Conselho Nacional de Justiça já estabeleceu que é um direito o 
casamento civil para a população LGBT. Isso é um direito que já está estabelecido" e ainda evoca a Constituição de 1988, ao afirmar que o estado é laico, nas suas palavras: "Nós vivemos em um estado laico, e no estado laico as pessoas têm que ser respeitadas independente dessas situações a que me referi antes". Ou seja, ascende seu argumento, ao mobilizar a voz de autoridade e o argumento baseado no consenso, afinal, Direitos Humanos é uma verdade universalmente aceita, é incontestável (PLATÃO; FIORIN, 2013).

Para continuar sua defesa de tese, afirma aos entrevistadores e aos interlocutores - e a seu auditório social - que o tema é uma agenda importante de seu projeto de Governo, caso seja eleita. E, ainda, constrói uma argumentação para que seus interlocutores aceitem sua tese de que vai atender às demandas da população LGBT+, a partir da argumentação na competência linguística, apresentando com clareza e lógica sua tese: ser contra o racismo, a homofobia, a discriminação de minorias. Ou seja, esta interação pressupõe outro auditório social, um público que provavelmente respeita os Direitos Humanos, que não admite falácias como argumentação para um assunto de interesse coletivo. Ao nos voltarmos à pergunta construída pelo convidado e dirigida à candidata, evidenciamos que a construção tem uma fundamentação em dados sobre o tema - situação de vulnerabilidade da população LGBT+ -, o convidado contextualiza a situação à pré-candidata e pergunta: "o que a população LGBT desse pais pode esperar de um possivel governo de Marina Silva, caso a senhora seja eleita?", ou seja, o convidado é bastante plausível em sua construção, convocando um debate democrático, sem qualificadores que potencializam uma polêmica. Esta pergunta também dá o tom à resposta da pré-candidata, que vê nessa contextualização, uma possibilidade de construir uma resposta bem argumentada, mobilizando todos os recursos argumentativos possíveis, já que ela mobilizou argumento de autoridade, convocando a Constituição. Visto que Direitos Humanos são de interesse universal, a entrevistada fez uso de argumentos baseados em provas e em raciocínio lógico para a construção de seu discurso. E ainda mobilizou argumento de competência linguística, ao construir um discurso claro, com citações relevantes à defesa de sua tese - favorável à defesa dos direitos humanos de todas as pessoas e das minorias também (PLATÃO; FIORIN, 2003).

Nessa perspectiva, ao alocarmos essa fala no contínuo da argumentação, percebemos que a interação revelou que a pré-candidata buscou construir um debate lógico, ao assumir a relevância de se debater a questão dos Direitos Humanos. No contexto dessa fala, identificase a importância de se tratar de formas de discriminação e preconceitos que ferem os princípios dos Direitos Humanos, o que se expressa na tese de que "Todas as pessoas têm que ser respeitadas independente da cor, da condição social, orientação sexual ou do credo religioso" e "que não se pode negligenciar o preconceito contra indios, negros, gays, mulheres, ciganos, e as pessoas que vivem em situação de vulnerabilidade." Com isso, a pré-candidata responde à pergunta do convidado e assume uma postura em defesa dos Direitos Humanos e das minorias - grupo no qual a população LGBT+ se insere no país. Dessa forma, evidenciamos que a argumentação da candidata primou pelo dissenso, isto é, pelo desacordo que faz parte da interação, que não rejeita e elimina nenhuma voz na interação, visto que buscou acordar sua tese com a do convidado, ao responder à questão e não somente à crítica revelada na contextualização da pergunta de que "Há um sentimento por outro lado difundido na população LGBT que enxerga uma certa desconfiança e credita uma falta de clareza do posicionamento da candidata". Com isso, visou alinhar seu posicionamento ao seu auditório social, que provavelmente se constituiu de minorias ali convocadas nessa interação, buscando uma aceitação unânime. Assim, a pré-candidata, a partir dessa construção, produziu um discurso político democrático, que primou pelo dissenso, ou, nas palavras de Amossy (2017), pelo dissenso enquanto motor da democracia, estabelecendo um debate lógico. Dessa forma, no contínuo da argumentação, localizamos tal discurso no extremo da persuasão, ou seja, a pré-candidata construiu uma argumentação que 
não deslegitimou nenhuma voz, ao contrário, assumiu as vozes, mas buscou defender sua tese.

\section{Considerações finais}

Ao propormos um estudo sobre a argumentação nos discursos dos pré-candidatos à presidência do Brasil em 2018, nosso objetivo foi identificar como se constrói a argumentação no discurso de dois pré-candidatos e verificar que estratégias discursivas são mobilizadas e que efeitos de sentido elas constroem na interação.

A partir das teorias mobilizadas, ressaltamos que a argumentação está ligada ao ato de persuadir, de levar o interlocutor a aceitar uma determinada tese, e não a apresentar provas de verdade. Sendo assim, faz-se necessário que cada locutor, ao mobilizar a modalidade argumentativa na construção de seu discurso, tenha ciência do que é argumentar e quais os tipos argumentativos que estão implicados nessa construção. Tendo noção de que quanto melhor são mobilizados os argumentos, maior a eficiência e mais difícil torna-se a refutar uma tese ou ponto de vista, consequentemente mais universalmente aceita uma tese será.

Ainda, ressaltamos que a argumentação sempre está presente nos discursos construídos na interação discursiva, porém, é mobilizada de forma distinta a depender das pessoas, do contexto e do auditório social que cada interação suscita. Vimos, também, que a argumentação pode ser alocada em um contínuo, que revela uma polarização constitutiva da argumentação, em que, de um lado encontra-se a persuasão - ou a busca da defesa de uma tese, sem a necessidade de deslegitimar nenhuma outra voz, busca o convencimento e engajamento do auditório pretendido - e, de outro, está a polêmica - um embate que visa anular o outro, e gera um espetáculo discursivo, que exclui a possibilidade de diálogo. Tal mobilização do contínuo argumentativo está intimamente ligada aos interlocutores e ao auditório construído em cada interação discursiva, que constituirá sempre um evento único e irrepetível, no interior do qual se manifestam relações dialógicas, isto é, relações de sentido, a depender de quais estratégias os locutores desejam construir na interação: convencer, polemizar, debater democraticamente; construir uma tese irrefutável; construir uma tese polêmica e frágil.

Por fim, consideramos essa abordagem teórica potente para refletir e analisar os discursos políticos ao permitir que nós - leitores, ouvintes, telespectadores, eleitores possamos realizar subjetivamente uma análise sobre o discurso de cada candidato, a partir das estratégias argumentativas por eles utilizadas e possamos refletir sobre quais discursos nos representam, e mais, possamos estabelecer relações de sentidos - relações dialógicas - a partir do que evidenciamos na face verbal (o dito), e na face não verbal (o presumido) dentro dessas interações discursivas.

\section{Referências}

AMOSSY, R. Apologia da polêmica. Tradução: Mônica Magalhães Cavalcante [et al.]. São Paulo: Contexto, 2017. 
BAKHTIN, M. (VOLOCHINOV). Marxismo e filosofia da linguagem. Tradução: Michel Lahud e Yara Frateschi Vieira. São Paulo: Hucitec, 2010a.

BAKHTIN, M. Estética da criação verbal. São Paulo: Martins Fontes, 2010b.

BRASIL. Código Penal Brasileiro. 1940. Disponível em:

http://www.planalto.gov.br/ccivil_03/decreto-lei/Del2848compilado.htm. Acesso em: 12 ago. 2019.

BRASIL. Lei 7.716, de 5 de janeiro de 1989. Disponível em:

http://www.planalto.gov.br/ccivil_03/Leis/L7716.htm. Acesso em: 12 ago. 2019.

CARTA CAPITAL. Pela terceira vez, Bolsonaro é condenado a indenizar Maria do Rosário. 2017. Disponível em: https://www.cartacapital.com.br/politica/pela-terceiravez-bolsonaro-e-condenado-a-indenizar-maria-do-rosário. Acesso em: 16 fev. 2019.

CONGRESSO EM FOCO. TSE diz que "Kit gay" não existiu e proíbe Bolsonaro de disseminar notícia falsa. 2018. Disponível em:

https://congressoemfoco.uol.com.br/eleicoes/tse-diz-que-kit-gay-nao-existiu-e-proibebolsonaro-de-disseminar-noticia-falsa/. Acesso em: 12 ago. 2019.

EL PAÍS. O que Bolsonaro já disse de fato sobre mulheres, negros e gays. 2018. Disponível em: https://brasil.elpais.com/brasil/2018/10/06/politica/1538859277_033603.html. Acesso em: 16 fev. 2019.

FARACO, C. A. Linguagem e diálogo: as ideias linguísticas do Círculo de Bakhtin. Curitiba: Edições Criar, 2003.

O GLOBO. Bolsonaro diz na TV que seus filhos não 'correm risco' de namorar negras ou virar gays porque foram 'muito bem-educados'. 2011. Disponível em: https://oglobo.globo.com/politica/bolsonaro-diz-na-tv-que-seus-filhos-nao-correm-riscode-namorar-negras-ou-virar-gays-porque-foram-muito-bem-educados-2804755. Acesso em: 12 ago. 2019.

PLATÃO, F. S.; FIORIN, J. L. Lições de texto: leitura e redação. 5. ed. São Paulo: Ática, 2003.

PRODANOV, C. C.; FREITAS, E. C. Metodologia do trabalho científico: métodos e técnicas da pesquisa e do trabalho acadêmico. 2. ed. Novo Hamburgo: Feevale, 2013. Disponível em: < http://www.feevale.br/Comum/midias/8807f05a-14d0-4d5b-b1ad1538f3aef538/E-book\%20Metodologia $\% 20$ do\%20Trabalho\%20Cientifico.pdf $>$. Acesso em: 12 ago. 2019.

TV CULTURA. Roda Viva | Marina Silva | 30/04/2018. Disponível em: http://tvcultura.com.br/videos/64894_roda-viva-marina-silva-30-04-2018.html. Acesso em: 12 ago. 2019.

TV CULTURA . Roda Viva | Jair Bolsonaro | 30/07/2018. Disponível em: http://tvcultura.com.br/videos/65961_roda-viva-jair-bolsonaro-30-07-2018.html. Acesso em: 12 ago. 2019. 